\title{
AN INVESTIGATION OF IMPACT OF IRON AND ALUMINIUM ADDITION ON THE ANAEROBIC DIGESTION PROCESS
}

\author{
Svetlana Ofverstrom \\ Ieva Sapkaite \\ Regimantas Dauknys \\ Vilnius Gediminas Technical University, Lithuania
}

\begin{abstract}
In this study, the impact of iron and aluminium salts addition on anaerobic digestion process was investigated. Mixture of primary and activated sludge collected at Vilnius wastewater treatment plant in Lithuania was digested under laboratory conditions by using anaerobic digester (W8, Amfield, UK). To compare the relative digestibility of iron-dosed (Fe-dosed) and aliuminium-iron-dosed (Al-Fe-dosed) sludge with un-dosed sludge three continuous experiments were made. Results showed that iron and aliuminium negatively impacted anaerobic digestion process by reducing the volume of biogas produced. Fe-dosed sludge produced $20-50 \%$ less biogas and Al-Fe-dosed sludge produced $30-40 \%$ less biogas in comparison to the same un-dosed sludge. VS destruction decreased during dosing of $\mathrm{Fe}$ or/and Al salt. Biogas composition was not measured during the experiments.
\end{abstract}

\section{KEYWORDS}

Wastewater sludge (primary and activated sludge), lab-scale anaerobic digestion, aliuminium salt, iron salt, biogas production.

\section{INTRODUCTION}

Nitrogen and phosphorus removal from wastewater is a way to avoid eutrophication of water bodies [1]. Usually there are two possible schemes to remove phosphorus - biological and chemical. The most often used method for phosphorus removal from wastewater is biological treatment. Chemical phosphorus removal involves the addition of a chemical coagulant, either aluminium (Al), iron (Fe), or lime. As a consequence of chemical phosphorus removal, the volume of sludge increases, between approximately $37 \%$ and $97 \%$ [2].

The effect of both $\mathrm{Al}$ and $\mathrm{Fe}$ on anaerobic digestion efficiency has been studied by a number of investigators with conflicting results. Gossett et al. found reduction of gas production from addition of both iron and aluminium $[3,7]$. Johnson et al. found the iron rich primary sludge from chemically enhanced treatment reduced gas production by $32 \%$ while Lee found that addition of iron increased gas production [4, 5, 7]. Jackson- Moss and Duncan found that addition of up to $5,650 \mathrm{mg} / \mathrm{L}$ had no effect on an upflow anaerobic sludge blanket reactor. [6, 7] There is no general consensus of chemical phosphorus removal impact on anaerobic digestion because it is difficult to isolate impact of chemical phosphorus removal from other site-specific variables, such as sludge age and wastewater composition $[8,9]$.

https://doi.org/10.15626/Eco-Tech.2010.059 
The objective of this study was to investigate any possible negative effect of aluminium (Al) or/and iron $(\mathrm{Fe})$ salt addition on biogas production and organic matter destruction during anaerobic digestion of mixture of primary and activated sludge.

\section{METHODOLOGY}

Experiment was held under laboratory conditions at Vilnius Gediminas technical university, Lithuania during April - June month, 2010. Laboratory-scale anaerobic digester model (W8, Armfield, UK) was used for experiments. The model was of two independently operating units of $4,8 \mathrm{~L}$ each The gas off-take from each reactor was taken into a volumetrically calibrated collector vessel $(300 \mathrm{ml})$ operating by water displacement $[10,11]$.

Primary and activated sludge was taken from wastewater treatment plant in Vilnius, Lithuania every $5^{\text {th }}$ day and stored in a refrigerator under $+4{ }^{\circ} \mathrm{C}$ conditions. Laboratory digesters were started by seeding with digested sludge from previous experiments of anaerobic digestion of un-dosed primary and activated sludge mixture [12]. Laboratory digesters were fed with primary and activated sludge (1:2) mixture, $0.24 \mathrm{~L} /$ day. The digesters were operated at mesophilic conditions $\left(35^{\circ} \mathrm{C}\right)$ with 20 -days solids retention time.

The experiments were three - anaerobic digestion of un-dosed, Fe-dosed and Al-Fe-dosed sludge mixtures. Doses of $\mathrm{Fe}$ and $\mathrm{Al}$ were selected according to Gothenborg (Sweden) WWTP average amounts of Fe and $\mathrm{Al}$ in digested sludge during 2008 year. It was obtained that the amount of Fe was 52-81 mgFe/gTS and Al was 13-29 mgAl/gTS. Minimum selected dose of Fe was $50 \mathrm{mgFe} / \mathrm{gTS}$ and maximum - 100mgFe/gTS, minimum dose of Al selected was $15 \mathrm{mgAl} / \mathrm{gTS}$ and maximum - 30mgAl/gTS (see Table 1).

The concentration of total solids (TS) in sludge mixture after the digestion of primary and activated sludge mixture using W8 model was $16.8 \mathrm{gTS} / \mathrm{L}$ [12].

The experimental doses of $\mathrm{FeCl}_{3} \cdot 6 \mathrm{H}_{2} \mathrm{O}$ and $\mathrm{Al}_{2}\left(\mathrm{SO}_{4}\right)_{3} \cdot 18 \mathrm{H}_{2} \mathrm{O}$ added are shown in Table 1.

Table 1. Selected experimental doses of Al and Fe salts

\begin{tabular}{|c|c|c|c|c|c|c|}
\hline Reactor & $\begin{array}{c}\mathrm{Fe}(\mathrm{III}), \\
\mathrm{mg} / \mathrm{gTS}\end{array}$ & $\begin{array}{c}\mathrm{FeCl}_{3} \cdot 6 \mathrm{H}_{2} \mathrm{O}, \\
\mathrm{g} / \mathrm{L}\end{array}$ & $\begin{array}{c}\mathrm{FeCl}_{3} \cdot 6 \mathrm{H}_{2} \mathrm{O}, \\
\mathrm{g} / \text { day }\end{array}$ & $\begin{array}{c}\mathrm{Al}(\mathrm{III}), \\
\mathrm{mg} / \mathrm{gTS}\end{array}$ & $\begin{array}{c}\mathrm{Al}_{2}\left(\mathrm{SO}_{4}\right)_{3} \cdot 18 \mathrm{H}_{2} \mathrm{O}, \\
\mathrm{g} / \mathrm{L}\end{array}$ & $\begin{array}{c}\mathrm{Al}_{2}\left(\mathrm{SO}_{4}\right)_{3} \cdot 18 \mathrm{H}_{2} \mathrm{O}, \\
\mathrm{g} / \text { day }\end{array}$ \\
\hline I & 50 & 4,17 & 1,0 & 15 & 0,77 & 0,19 \\
\hline II & 100 & 8,34 & 2,0 & 30 & 1,54 & 0,37 \\
\hline
\end{tabular}

Selected maximum and minimum doses of $\mathrm{FeCl}_{3} \cdot 6 \mathrm{H}_{2} \mathrm{O}$ were used after the control period of 20 days without any chemical addition. The duration of the dosing period was 20 days. The chemicals were continuously dosed into the sludge mixture from a stock solution containing an appropriate quantity of $\mathrm{Fe}$ and Al-Fe salt together with distilled water. After 20 days of dosing of $\mathrm{Fe}$ salt selected $\mathrm{Fe}$ salt dosing was continued with addition of maximum and minimum amounts of $\mathrm{Al}_{2}\left(\mathrm{SO}_{4}\right)_{3} \cdot 18 \mathrm{H}_{2} \mathrm{O}$.

During experiments $\mathrm{pH}$, alkalinity (ALK), volatile fatty acids (VFA), total solids (TS), volatile solids (VS) were measured regularly and biogas production was monitored. The relative digestibility was assessed by measuring two parameters: (1) biogas volume, (2) organic matter destruction. The gas off-take from each reactor was taken to a volumetrically calibrated collector vessel $(300 \mathrm{ml})$ operating by water displacement. Values were calculated 
from 4-days overage biogas production. The organic matter destruction was calculated from measuring the VS concentration before and after digestion according to Standard Methods $[13]$.

\section{RESULTS AND DISCUSSION}

An examination of $\mathrm{pH}$, alkalinity and volatile fatty acid data (see Table 2) showed that there was a significant reduction of alkalinity in digesters receiving chemically derived sludge with maximum dose of $\mathrm{Fe}$ or/and $\mathrm{Al}$ salt. Associated with this lower alkalinity was a lower $\mathrm{pH}$ than in the control unit. In the digester receiving maximum dose of $\mathrm{Fe}$ or/and $\mathrm{Al}$ salts, the alkalinity decreased to a value of only $300-400 \mathrm{mg} / \mathrm{L}$ as $\mathrm{CaCO}_{3}$, at which time the $\mathrm{pH}$ dropped to 6.06 .

The $\mathrm{pH}$ was too low for the methane-producing bacteria, with the result that failure occurred.

Table 2. Experimental parameters of un-dosed, Fe-dosed and Al-Fe dosed sludge mixture digestion

\begin{tabular}{|l|c|c|c|c|c|}
\hline \multicolumn{1}{|c|}{ Parameter } & $\begin{array}{c}\text { Control } \\
\text { digester }\end{array}$ & $\begin{array}{c}\text { Fe-dosed } \\
\text { sludge (min) }\end{array}$ & $\begin{array}{c}\text { Fe-dosed } \\
\text { sludge } \\
\text { (max) }\end{array}$ & $\begin{array}{c}\text { Al-Fe-dosed } \\
\text { sludge (min) }\end{array}$ & $\begin{array}{c}\text { Al-Fe-dosed } \\
\text { sludge (max) }\end{array}$ \\
\hline Load, g BSM/L/d & $0.67-1.01$ & $0.70-0.75$ & $0.70-0.75$ & $0.85-0.88$ & $0.85-0.88$ \\
\hline FS TS, g/L & $15.8-23.8$ & $18.2-25.5$ & $18.2-25.2$ & $18.2-25.5$ & $18.2-25.2$ \\
\hline DS TS, g/L & $17.8-23.8$ & $17.6-23.2$ & $24.4-32.2$ & $22.2-22.5$ & 24.0 \\
\hline VS destruction, \% & $21-32$ & $14-18$ & $13-14$ & $12-17$ & $13-14$ \\
\hline pH & $6.80-7.07$ & $6.52-6.72$ & $6.25-6.32$ & $6.52-6.80$ & $6.06-6.26$ \\
\hline T, ${ }^{\circ} \mathrm{C}$ & $34.6-35.4$ & $34.8-35.5$ & $34.9-35.5$ & $34.6-37.0$ & $35.0-35.5$ \\
\hline VFA, mg/L & $120-300$ & $180-240$ & $120-180$ & $180-300$ & $180-250$ \\
\hline ALK, mg/L & $1250-1750$ & $900-1350$ & $500-650$ & $700-1000$ & $300-400$ \\
\hline Biogas, ml/d & $100-150$ & $80-125$ & $50-80$ & $100-130$ & $80-95$ \\
\hline
\end{tabular}

FS TS - fed sludge TS, g/L, , g/L, DS TS - digested sludge TS, g/L, VFA- volatile fatty acids as Acetic, mg/L, ALK - alkalinity as $\mathrm{CaCO}_{3}, \mathrm{mg} / \mathrm{L}$

During digestion of un-dosed sludge mixture VS destruction was 21-32\%. VS destruction of Fe-dosed sludge was from $14-18 \%$ and $13-14 \%$ for minimum and maximum doses. VS destruction of Al-Fe-dosed sludge mixture was $12-17 \%$ and $13-14 \%$ for minimum and maximum doses accordingly. Gosset et. al. investigated the effect of the addition of iron and aluminium salts to sludge on the digestabiloity and found that both iron and aluminium reduced VS destruction by about $10 \%$. Novak and Park found that iron addition had little impact on the volatile solids destruction by anaerobic digestion. $[3,14]$.

Daily biogas productions from un-dosed Fe-dosed and Al-Fe-dosed sludge mixture are shown in Figure 1 and Figure 2 as 4-day running averages. In all cases, deviations from the control un-dosed sludge were evident from the beginning. Biogas production from un-dosed primary and activated sludge mixture was from $100 \mathrm{ml} /$ day to $150 \mathrm{~mL} / \mathrm{d}$, depending on VS load of fed sludge mixture. Within first days of addition of Fe salt to sludge mixture biogas production decreased to about $20-25 \%$ for Fe-dosed sludge (minimum dose) and $50 \%$ of normal level for Fe-dosed sludge mixture with maximum dose of Fe salt (see Figure 1). 


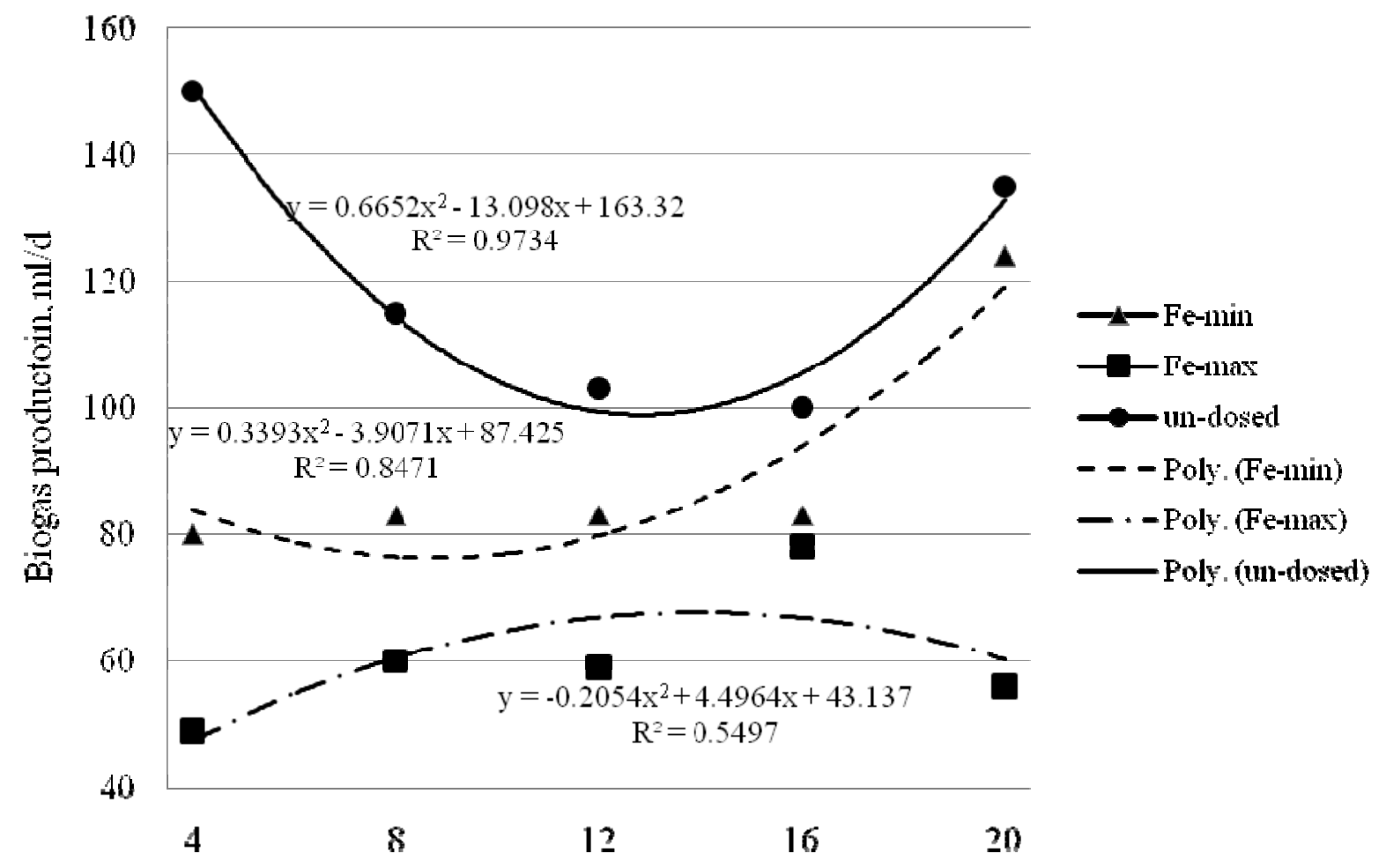

Figure 1. Biogas formation from un-dosed and Fe-dosed sludge mixture

Biogas production remained depressed during most of time for Fe-dosed sludge (maximum dose) but biogas production from Fe-dosed sludge with minimum dose of Fe salt increased from approx. 12-15 days of experiment and until the end of experiment biogas production from Fe-dosed (minimum dose) was close to biogas production from un-dosed sludge. 


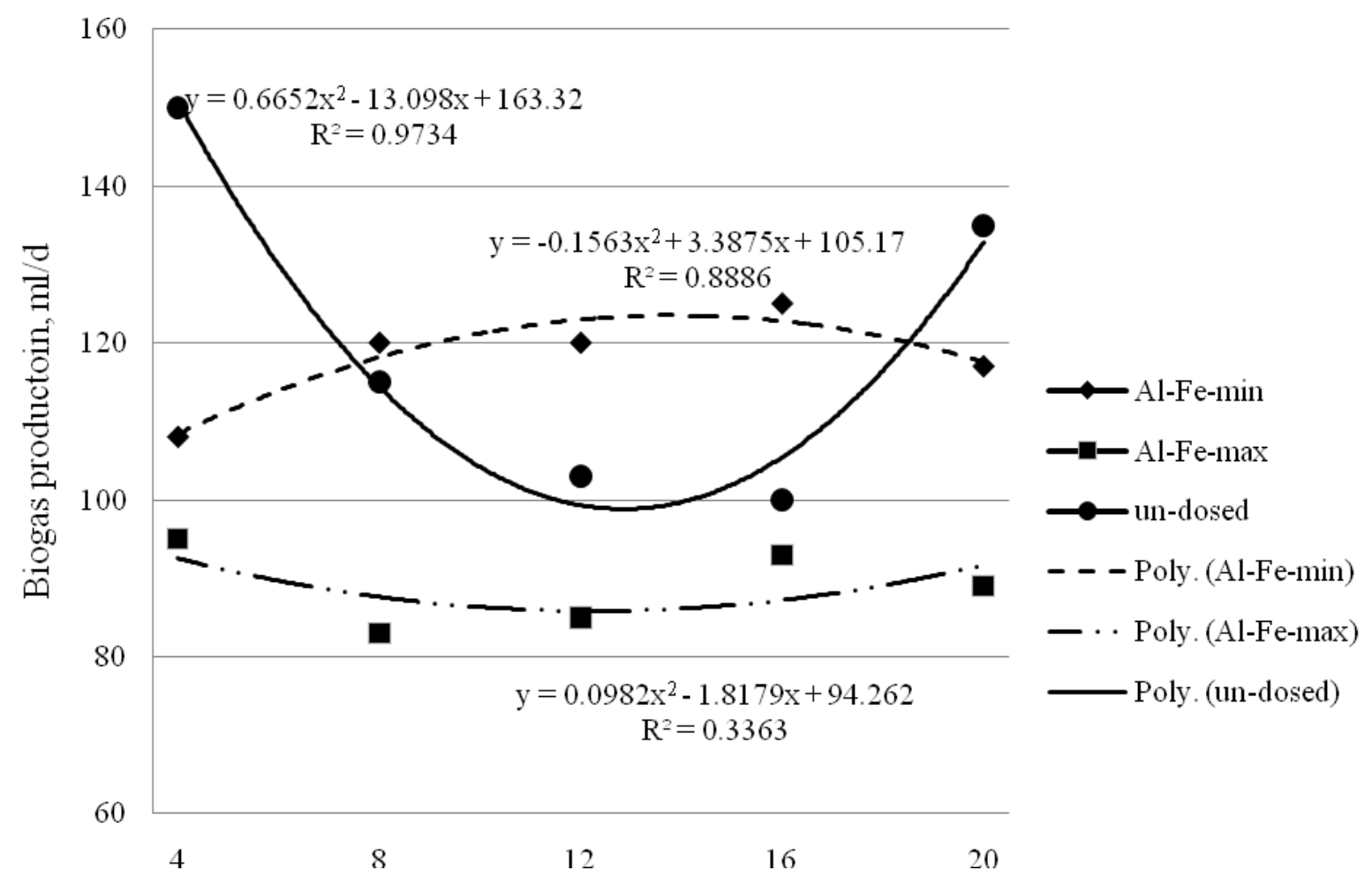

Figure 2. Biogas production from Al-Fe-dosed sludge mixture

During addition of both $\mathrm{Al}$ and $\mathrm{Fe}$ salt to sludge mixture biogas production from Al-Fe-dosed sludge increased approx. 10-20\% compare to biogas production from Fe-dosed sludge (see Figure 2). Biogas composition was not measured during experiment. Biogas production from Al-Fe-dosed slugde (minimum dose) was more stable during experiment than biogas production from un-dosed sludge.

\section{CONCLUSIONS}

The results obtained from the lab-scale experiments demonstrated the negative effect of aliuminium or iron salt on anaerobic digestion of primary and activated sludge mixture.

During dosing of minimum and maximum doses of $\mathrm{FeCl}_{3} \cdot 6 \mathrm{H}_{2} \mathrm{O}$ into sludge mixture VS destruction in digested sludge was decreasing compare to un-dosed sludge mixture up to $30 \%$.

Addition of $\mathrm{FeCl}_{3} \cdot 6 \mathrm{H}_{2} \mathrm{O}$ salt had negative effect on biogas production. Biogas production from Fe-dosed sludge mixture decreased to about $20-25 \%$ for Fe-dosed sludge with minimum dose of Fe salt added and 50\% of normal level for Fe-dosed sludge mixture with maximum dose of Fe salt added.

Addition of $\mathrm{Al}_{2}\left(\mathrm{SO}_{4}\right)_{3} \cdot 18 \mathrm{H}_{2} \mathrm{O}$ salt into Fe-dosed sludge mixture raised biogas production up to $10-20 \%$ compare to biogas production from Fe-dosed sludge. 
In order to ave the compehensive understanding of $\mathrm{Al}$ and $\mathrm{Fe}$ affect on anaerobic digestion of primary and activated sludge mixture it is usefull to measure composition of biogas produced during anaerobic digestion.

\section{REFERENCES}

[1] Dauknys, R.; Vabolienè, G.; Valentukevičienè, M.; Rimeka, M., 2009. Influence of substrate on biological removal of phosphorus. Ekologija 55 (3-4), 220-225.

[2] Yeoman, S., Stephenson, T., Lester, J., Perry, R., 1988. The removal of phosphorus during wastewater treatment: a review. Environmental Pollution 49, 183-255.

[3] Gossett, J. M., Wilson, J. C., Evans, D. S. \& McCarty, P. L. 1978 Anaerobic digestion of sludge from chemical treatment. J. Water Pollut. Control Fed. 50(3), 533-542.

[4] Johnson, D.; Carliell-Marquet, C.; Forster, C., 2003 An examination of the treatment of iron-dosed waste activated sludge by anaerobic digestion. Environmental Technology. 24, 937-945

[5] Lee, H. 2008. Stimulation of anerobic digestion of thickened sewage sludge by iron richsludge produced by the Fenton method. J. Biosci. Bioeng. 106(1), 107-110

[6] Jackson-Moss, C. A. \& Duncan, J. R. 1990 The effect of iron on anerobic digestion. Biotechnol. Lett. 12(2), 149-154.

[7] Novak, J.T.; Verma, N.; Muller, C.D. 2007. The role of iron and aluminium in digestion and odor formation. Water Science and Technology 56(9), 59-65.

[8] Bonzonella, D., Pavan, P., Battistoni, P., Cecchi, F., 2005. Mesophilic anaerobic digestion of waste activated sludge: influence of the solid retention time in the wastewater treatment process. Process Biochemistry 40, 1453-1460.

[9] Smith, J.A.; Carliell-Marquet, C.M., 2008. The digestibility of iron-dosed activated sludge. Bioresource Technology 99, 8585-8592.

[10] Blonskaja, V.; Menert, A.; Vilu R. 2003. Use of two-stage anaerobic treatment for distillery waste. Advances in Neviromental Research 7, 671-678.

[11] Menert, A.; Liiders, M.; Kurissoo, T; Vilu, R., 2001. Microcalorimetric monitoring of anaerobic digestion processes. Journal of Thermal Analysis and Calorimetry. 64: 281-291

[12] Ofverstrom, S., Sapkaite, I., Dauknys, R., 2010. Research and analyses of anaerobic digestion of Vilnius WWTP sludge mix. In: Proceedings of the 13th Conference for Lithuanian Junior Researches Science for Future: Engineering Systems for Buidings, April 15-16, 2010, Vilnius, Lithuania, Technika pp. 72-75.

[13] APHA. 2000. Standard Methods for the Examination of Water and Water Water. 18th ed. Washington DC. USA: American Public Health Association/American Water Works Association/Water Environment Federation.

[14] Novak J.T. and Park C.M. 2010. The effect of iron and aluminium for phosphorus removal. Water Science and Technology 62.2. 